\title{
The role of thyroid hormones in carotid arterial wall remodeling in women
}

\author{
MAIDA SEFEROVIC SARIC ${ }^{1}$, MILJENKA-JELENA JURASIC $^{2}$, HRVOJE BUDINCEVIC $^{3}$, MILAN $^{2}$ \\ MILOSEVIC $^{4}$, BOJANA KRANJCEC ${ }^{5}$, SANJA KOVACIC $^{1}$, JANA LESKOVAR $^{1}$, VIDA DEMARIN ${ }^{6}$
}

\footnotetext{
${ }^{1}$ Department of Neurology, Zabok General Hospital and Hospital of Croatian Veterans, Bracak 8, 49210 Zabok, Croatia

${ }^{2}$ Department of Neurology, Sestre Milosrdnice University Hospital Center, Vinogradska cesta 29, 10000 Zagreb, Croatia

${ }^{3}$ Department of Neurology, University Hospital Sveti Duh, Sveti Duh 64, 10000 Zagreb, Croatia

${ }^{4}$ Department of Medical Statistics, Epidemiology and Medical Informatics, University of Zagreb Andrija Stampar School of Public Health, Johna Davidsona Rockfellera 4, 10000, Zagreb, Croatia

${ }^{5}$ Medical and Biochemical Laboratory, Zabok General Hospital and Hospital of Croatian Veterans, Bracak 8, 49210 Zabok, Croatia

${ }^{6}$ Croatian Academy of Sciences and Arts, Trg Nikole Subica Zrinskog 11, 10000 Zagreb, Croatia
}

\begin{abstract}
Introduction: Thyroid hormones affect the cardiovascular system, but the precise mechanisms of their effects on the development of atherosclerosis are not entirely clear. The relationship between subclinical hypothyroidism, dyslipidemia and carotid atherosclerosis has been widely investigated, but the findings were controversial. The aim of the present study was to determine whether female subjects with subclinical hypothyroidism (SHypo) have increased carotid intima-media thickness (IMT) compared with euthyroid subjects, as well as to examine the association of SHypo, carotid atherosclerosis and dyslipidemia.

Methods: This research included 100 women aged 30 to 70 years who were divided into two groups: the SHypo group including subjects with signs of subclinical hypothyroidism and the control group of euthyroid subjects. Carotid IMT thickness using B mode ultrasound was determined and its correlation with serum concentrations of fT4, TSH, CRP, and lipid profile including small dense LDL (sdLDL) was analysed.

Results: Subjects with SHypo had significantly increased carotid IMT (IMT $\geq 75$ th centile) in all three measured segments of the right $(p<0.001)$ and the left $(p=0.001)$ carotid artery compared to the control group, with a significantly more frequent appearance of plaque $(25 \%$ vs. $9 \% ; p=0.05)$. Significant positive correlations were found between higher TSH and higher IMT values. Increased age, LDL cholesterol, and TSH predicted thickening of the carotid artery IMT.

Conclusions: It is important to screen people showing early, subclinical signs of thyroid gland dysfunction due to its impact on carotid atherosclerosis development.
\end{abstract}

Key words: Carotid intima-media thickness (IMT), cerebrovascular diseases, dyslipidemias, hypothyroidism, LDL cholesterol.

\section{What is new? What is important?}

Subjects with subclinical hypothyroidism have elevated carotid intima-media thickness (IMT). It is important to screen people showing early, subclinical signs of thyroid gland dysfunction to prevent development of atherosclerosis and its complications. Along with assessment of conventional risk factors, carotid IMT as a marker of atherosclerosis using B-mode ultrasound should be measured.

\section{INTRODUCTION}

Subclinical hypothyroidism (SHypo) is a condition characterized by mild to moderate thyroid dysfunction with normal thyroid hormones serum levels, but mildly elevated TSH (thyroidstimulating hormone, thyrotropin). The prevalence of this condition is $4-8.5 \%$ in adulthood, and it increases with aging to be found in $20 \%$ of older women [1]. Although the link between SHypo and cardiovascular disease (CVD) is known, its relevance in the process of atherosclerosis development remains a topic of debate $[2,3]$.

Carotid atherosclerotic disease begins gradually, first with the development of asymptomatic changes in the blood vessels, thereby initiating a series of adverse events that might end in a stroke 
[4]. Subclinical changes are characterized by the appearance of thickening of the intimal and medial part of the carotid artery wall (intima-media thickness, IMT), a functional disorder of elasticity in the extracranial cerebral vessels and, lastly, formation of carotid plaques [5]. These initial, subclinical changes of the carotid vessels can be quantified by measuring IMT thickness using Bmode ultrasound $[4,6,7]$.

So far in the literature, association between thyroid function, atherosclerosis and IMT was reported, but the exact mechanisms of the influence of thyroid hormones on the development of atherosclerosis have not yet been fully elucidated $[2,3,8]$. In their systematic review, Karagiannis et al. found that correlation between SHypo and increased IMT may be due to arterial hypertension, dyslipidemia and elevated TSH levels [9]. In a meta-analysis Gong et al. showed that SHypo was associated with endothelial dysfunction in which hypertension and dyslipidemia play a crucial role [10].

The aim of this study was to determine whether female subjects with SHypo have increased carotid IMT compared with euthyroid subjects, as well as to examine the association of SHypo, carotid atherosclerosis and dyslipidemia.

\section{MATERIAL AND METHODS}

This is a retrospective study based on data collected between December 2014 and December 2015 at Zabok General Hospital and Hospital of Croatian Veterans. The study was approved by the Ethics Committee of Zabok General Hospital and Hospital of Croatian Veterans, as well as the Ethics Committee of the University of Zagreb School of Medicine, and conducted in accordance with the principles of Good Clinical Practice and Declaration of Helsinki. All subjects signed the informed consent form.

The study included women who were diagnosed with subclinical hypothyroidism (SHypo group), as well as those whose thyroid function was determined to be normal (control, euthyroid group). Along with thyroid hormones levels (fT4 - free thyroxine, TSH), lipid profile (total cholesterol, HDL, LDL, small dense LDL sdLDL, triglyceride) and CRP (C - reactive protein) were determined during the first stage of our research where association of SHypo and dyslipidemia was examined [11]. In the present study, these variables were used for the analysis of their possible effects on carotid atherosclerosis measured by IMT.

Exclusion criteria were: fT4 values outside the reference range, TSH values $>10 \mathrm{mIU} / \mathrm{L}$ or $<0.35 \mathrm{mIU} / \mathrm{L}$, pregnancy, previously diagnosed thyroid disease or thyroid surgery, primary hyperlipidemia, ovarian dysfunction, ovariectomy, hysterectomy, diabetes mellitus, liver or kidney disease, chronic pancreatic inflammation, malignancy, previous heart attack, previous stroke, previous carotid artery surgery, use of medication for regulation of thyroid function or lipid metabolism, amiodarone use, and high fever or signs of inflammation.

\section{Carotid artery ultrasound - IMT determination}

Carotid artery examination was performed using Aloka SSD 4000 with a linear $10 \mathrm{MHz}$ probe (UST -5524-7.5). The technique of carotid IMT evaluation was performed according to the standardized protocol [12] using B-mode in the three segments of carotid artery: $\mathrm{CB}$ - carotid bifurcation, CCA - common carotid artery, ICA internal carotid artery.

\section{Sociodemographic and clinical features}

The following measurements were determined for all subjects: age, body height and weight, and body mass index (BMI) according to the formula: $\mathrm{BMI}=\mathrm{kg} / \mathrm{m}^{2}$. Habits such as smoking and alcohol consumption were also noted. Hormonal status such as menopause and medication use were recorded. Family history for cardiovascular and cerebrovascular diseases was considered positive if the subject had at least one first relative with a stroke or heart attack.

\section{Statistical analysis}

Continuous data were presented using median with interquartile ranges and arithmetic means with standard deviations for comparison with available literature data. Differences in quantitative values were analyzed by MannWhitney U-test. Differences in categorical values were analyzed by Fisher's exact test. Spearman's rho correlation coefficients between TSH values and IMT were calculated. All $p$ values less than 0.05 were considered statistically significant.

For this analysis we used IBM SPSS Statistics software, version 24.0.0.12. 


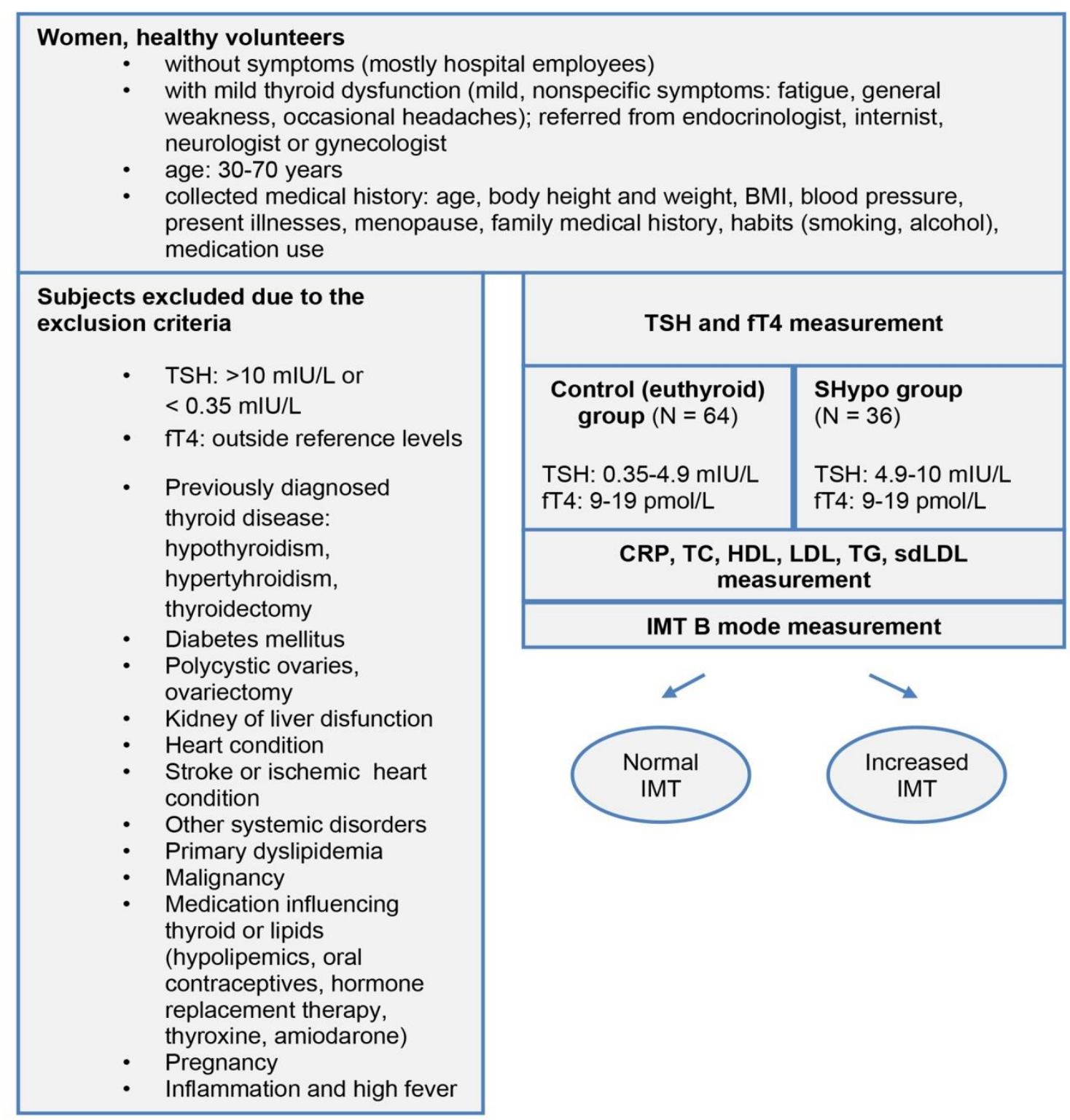

$\mathrm{BH}$ - body height; BW - body weight; BMI - body mass index; CRP - C-reactive protein; fT4 - free thyroxine; HDL - high-density lipoprotein; IMT - intima-media thickness; LDL- low-density lipoprotein; sdLDL - small dense low-density lipoprotein; TC - total cholesterol; TG - triglycerides; TSH thyrotropin

Figure 1. The study flow chart.

\section{RESULTS}

This study included 100 subjects who were divided into two groups: the SHypo group $(\mathrm{N}=36)$ and the control (euthyroid) group $(\mathrm{N}=64)$. The mean age of all subjects was $49.46 \pm 10.30$ years, in the SHypo group $50.85 \pm 10.74$ years, and in the control (euthyroid) group $48.67 \pm 10.05$ years (Table $1)$. Considering that there were no significant differences between the studied groups in age $(p=$
$0.21)$ and body mass index $(p=0.07)$, it can be stated that the tested groups were uniform in both age and body mass index. The groups also did not significantly differ in alcohol consumption ( $p=0.06)$, smoking $(p=0.10)$, menopause status $(p=0.15)$ and medication use (Table 2). Arterial hypertension was present in $42 \%$ of the SHypo and $30 \%$ of the euthyroid subjects $(p=0.27)$, whereas positive family history was significantly more common $(p=0.02)$ in the SHypo group 
Table 1

The comparison of the quantitative clinical and laboratory variables in the SHypo and control group: Mann-Whitney U-test. Variables were expressed as arithmetic means with standard deviations

\begin{tabular}{|c|c|c|c|}
\hline & SHypo & Control & $p$ value \\
\hline Age (years) & $50.86 \pm 10.74$ & $48.67 \pm 10.05$ & 0.205 \\
\hline Body weight (kg) & $73.5 \pm 11.84$ & $68.30 \pm 10.64$ & 0.030 \\
\hline Body height (cm) & $165.19 \pm 5.33$ & $164.20 \pm 5.47$ & 0.333 \\
\hline BMI $\left(\mathrm{kg} / \mathrm{m}^{2}\right)$ & $26.99 \pm 4.47$ & $25.35 \pm 3.90$ & 0.073 \\
\hline Cholesterol (mmol/L) & $6.15 \pm 1.27$ & $5.68 \pm 0.93$ & 0.070 \\
\hline Tryglicerides (mmol/L) & $1.37 \pm 0.62$ & $1.22 \pm 0.58$ & 0.251 \\
\hline HDL (mmol/L) & $1.50 \pm 0.26$ & $1.57 \pm 0.34$ & 0.291 \\
\hline LDL (mmol/L) & $3.80 \pm 0.97$ & $3.45 \pm 0.91$ & 0.094 \\
\hline sdLDL (mmol/L) & $1.00 \pm 0.48$ & $0.80 \pm 0.31$ & 0.047 \\
\hline LDL/HDL index & $2.60 \pm 0.80$ & $2.31 \pm 0.81$ & 0.112 \\
\hline Cholesterol/HDL index & $4.18 \pm 0.99$ & $3.76 \pm 0.93$ & 0.049 \\
\hline CRP (mg/L) & $2.21 \pm 1.94$ & $2.15 \pm 2.95$ & 0.321 \\
\hline $\mathrm{TSH}(\mathrm{mlU} / \mathrm{L})$ & $6.12 \pm 1.20$ & $2.07 \pm 1.29$ & $<0.001$ \\
\hline fT4 (pmol/L) & $12.31 \pm 1.07$ & $13.32 \pm 1.47$ & 0.001 \\
\hline
\end{tabular}

BH - body height; BW - body weight; BMI - body mass index; CRP - C-reactive protein; fT4 - free tyroxine; HDL - high-density lipoprotein; LDL - low-density lipoprotein; sdLDL - small dense LDL; TSH - thyrotropin

\section{Table 2}

The comparison of the qualitative variables collected through medical history in the SHypo and control group: Fisher's exact test. Variables were axpressed as percentages

\begin{tabular}{lcrr}
\hline & SHypo & Control & $\boldsymbol{p}$ value \\
& & & 0.055 \\
\hline Alcohol consumption & $1.6 \%$ & $11.1 \%$ & 0.999 \\
\hline Smoking & $13.9 \%$ & $14.1 \%$ & 0.149 \\
\hline Menopause & $61.1 \%$ & $45.3 \%$ & 0.273 \\
\hline Arterial hypertension & $41.7 \%$ & $29.7 \%$ & \\
\hline
\end{tabular}




\begin{tabular}{lccr} 
& & & (Tabel 2 continued) \\
\hline Positive family history & $58.2 \%$ & $34.3 \%$ & $\mathbf{0 . 0 2 3}$ \\
\hline ACE inhibitors & $13.9 \%$ & $14.1 \%$ & 0.999 \\
\hline Ca channel blockers & $16.7 \%$ & $6.3 \%$ & 0.161 \\
\hline Beta-blockers & $27.8 \%$ & $14.1 \%$ & 0.114 \\
\hline Angiotensine II antagonists & $11.1 \%$ & $3.1 \%$ & 0.184 \\
\hline Diuretics & $16.7 \%$ & $6.3 \%$ & 0.161 \\
\hline Analgetics & $25.0 \%$ & $25.0 \%$ & 1.000 \\
\hline PPI & $11.1 \%$ & $3.1 \%$ & 0.184 \\
\hline Supplements & 25.0 & 12.5 & 0.164 \\
\hline Triptans & $2.8 \%$ & $1.6 \%$ & 0.999 \\
\hline Sedatives & $0.0 \%$ & $7.8 \%$ & 0.156 \\
\hline ASA & $11.1 \%$ & $1.6 \%$ & 0.055 \\
\hline Antidepressants & $2.8 \%$ & $3.1 \%$ & 0.999 \\
\hline Other medications & $2.8 \%$ & $12.5 \%$ & 0.151 \\
\hline
\end{tabular}

Measured by $\mathrm{B}$ mode ultrasound, the subjects with SHypo had significantly higher values of IMT (IMT $\geq 75$ th centile) in all three measured segments of the right $(p<0.001)$ and left $(p=0.001)$ carotid artery relative to the control (euthyroid) group (Figure 2), with a significantly more frequent appearance of plaque than in the control group ( $25 \%$ vs. $9 \% ; p=0.05)$.

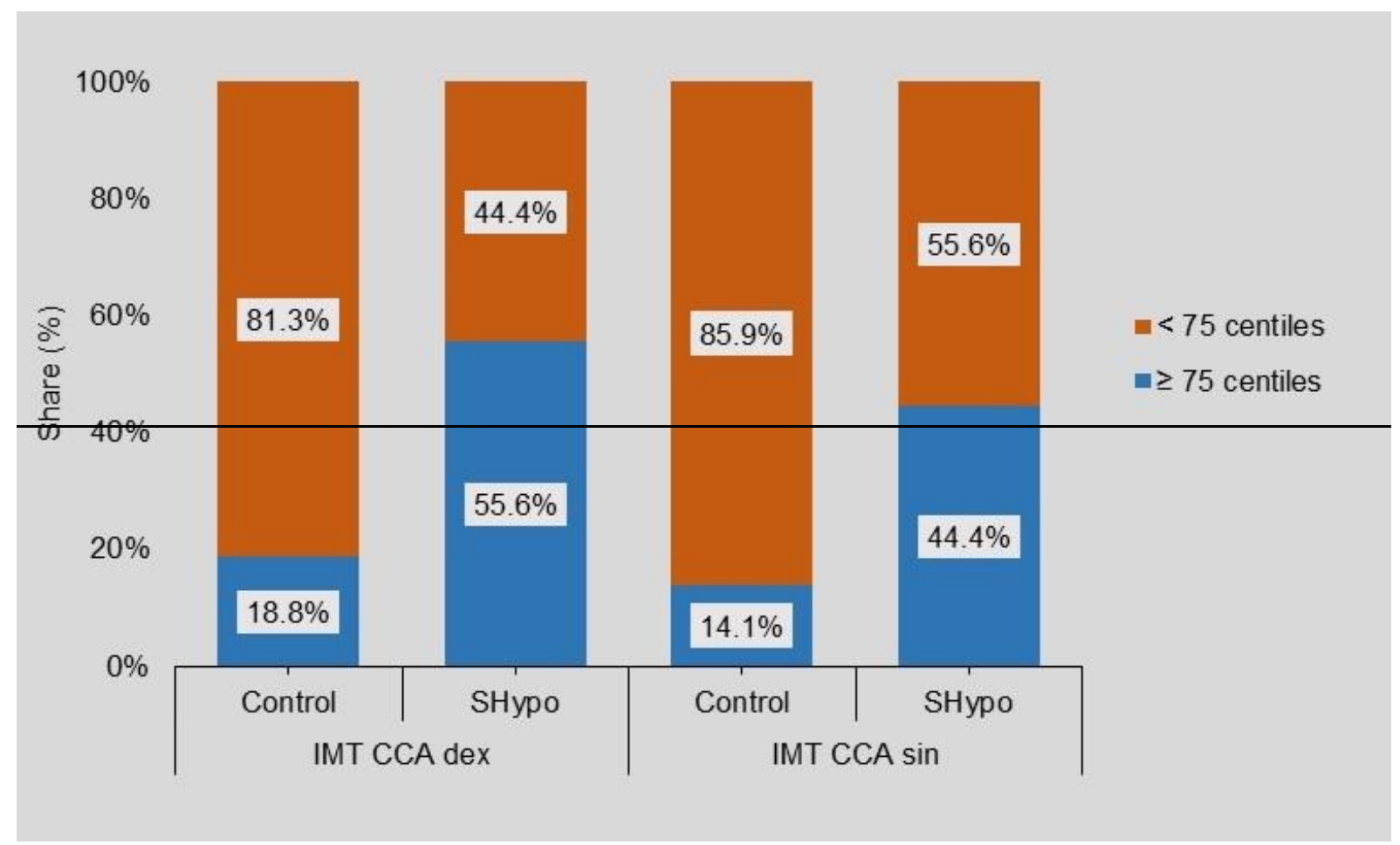

CCA - common cartiod artery, IMT - intima media thickness, SHypo - subclinical hypothyroidism.

Figure 2. Differences in IMT values of the right and left CCA in respect to TSH $>4.9 \mathrm{mlU} / \mathrm{L}$

Greater proportions of the SHypo subjects had significantly increased IMT of the right $(p<0.001)$ and the left CCA $(p=0.001)$. 
Spearman's correlation coefficients between TSH and IMT values for all three segments in the total sample and within each age group are shown in Table 3. Significant medium-strong positive correlations of TSH with all examined IMT values were recorded in the total sample indicating that higher TSH values are associated with higher IMT values.

Table 3

Spearman's correlation coefficients between TSH values and IMT in three segments of left and right carotid artery with regards to age of the subjects

\begin{tabular}{|c|c|c|c|c|c|c|}
\hline & & All subjects & $\begin{array}{c}<40 \\
\text { years }\end{array}$ & $\begin{array}{l}41-50 \\
\text { years }\end{array}$ & $\begin{array}{l}51-60 \\
\text { years }\end{array}$ & $\begin{array}{c}\geq 61 \\
\text { years }\end{array}$ \\
\hline IMT CCA dex (mm) & $\begin{array}{l}\text { Correlation coefficient } \\
p \text { value } \\
\text { Number of subjects }\end{array}$ & $\begin{array}{c}0.447 \\
<\mathbf{0 . 0 0 1} \\
100\end{array}$ & $\begin{array}{c}0.553 \\
\mathbf{0 . 0 0 9} \\
21\end{array}$ & $\begin{array}{c}0.461 \\
\mathbf{0 . 0 2 3} \\
24\end{array}$ & $\begin{array}{c}0.443 \\
\mathbf{0 . 0 0 6} \\
37\end{array}$ & $\begin{array}{c}0.641 \\
\mathbf{0 . 0 0 4} \\
18\end{array}$ \\
\hline IMT CB dex (mm) & $\begin{array}{l}\text { Correlation coefficient } \\
p \text { value } \\
\text { Number of subjects }\end{array}$ & $\begin{array}{l}0.416 \\
<\mathbf{0 . 0 0 1} \\
94 * *\end{array}$ & $\begin{array}{c}0.436 \\
\mathbf{0 . 0 4 8} \\
21\end{array}$ & $\begin{array}{c}0.400 \\
0.053 \\
24\end{array}$ & $\begin{array}{c}0.531 \\
\mathbf{0 . 0 0 1} \\
34\end{array}$ & $\begin{array}{c}0.236 \\
0.397 \\
15\end{array}$ \\
\hline IMT ICA dex (mm) & $\begin{array}{l}\text { Correlation coefficient } \\
p \text { value } \\
\text { Number of subjects }\end{array}$ & $\begin{array}{l}0.327 \\
\mathbf{0 . 0 0 1} \\
96 * *\end{array}$ & $\begin{array}{c}0.460 \\
\mathbf{0 . 0 3 6} \\
21\end{array}$ & $\begin{array}{c}0.452 \\
\mathbf{0 . 0 2 6} \\
24\end{array}$ & $\begin{array}{c}0.332 \\
0.059 \\
33\end{array}$ & $\begin{array}{c}0.355 \\
0.149 \\
18\end{array}$ \\
\hline IMT CCA $\sin (\mathbf{m m})$ & $\begin{array}{l}\text { Correlation coefficient } \\
p \text { value } \\
\text { Number of subjects }\end{array}$ & $\begin{array}{c}0.432 \\
<\mathbf{0 . 0 0 1} \\
100\end{array}$ & $\begin{array}{c}0.674 \\
\mathbf{0 . 0 0 1} \\
21\end{array}$ & $\begin{array}{c}0.491 \\
\mathbf{0 . 0 1 5} \\
24\end{array}$ & $\begin{array}{c}0.508 \\
\mathbf{0 . 0 0 1} \\
37\end{array}$ & $\begin{array}{c}0.421 \\
0.082 \\
18\end{array}$ \\
\hline IMT CB $\sin (\mathbf{m m})$ & $\begin{array}{l}\text { Correlation coefficient } \\
p \text { value } \\
\text { Number of subjects }\end{array}$ & $\begin{array}{l}0.361 \\
<\mathbf{0 . 0 0 1} \\
92 * *\end{array}$ & $\begin{array}{c}0.344 \\
0.127 \\
21\end{array}$ & $\begin{array}{c}0.470 \\
\mathbf{0 . 0 2 4} \\
23\end{array}$ & $\begin{array}{c}0.450 \\
\mathbf{0 . 0 0 7} \\
35\end{array}$ & $\begin{array}{c}0.362 \\
0.224 \\
13\end{array}$ \\
\hline IMT ICA $\sin (\mathbf{m m})$ & $\begin{array}{l}\text { Correlation coefficient } \\
p \text { value } \\
\text { Number of subjects }\end{array}$ & $\begin{array}{c}0.396 \\
<\mathbf{0 . 0 0 1} \\
94 * *\end{array}$ & $\begin{array}{c}0.398 \\
0.074 \\
21\end{array}$ & $\begin{array}{c}0.373 \\
0.080 \\
23\end{array}$ & $\begin{array}{c}0.491 \\
\mathbf{0 . 0 0 3} \\
34\end{array}$ & $\begin{array}{c}0.219 \\
0.414 \\
16\end{array}$ \\
\hline
\end{tabular}

CB - carotid bifurcation; CCA - common carotid artery; ICA - internal carotid artery; IMT - intima-media thickness

**In some subjects IMT could not be measured in all carotid segments due to the presence of plaque.

The prediction of the average IMT values of the right and left CCA by univariate and multivariate regression analysis in shown in Table 4. At the univariate analysis level, 18 predictor variables (age, cholesterol, triglycerides, LDL, sdLDL, LDL/HDL index, cholesterol/HDL index, TSH, CRP, BMI, alcohol consumption, arterial hypertension, menopause, ACE inhibitors, $\mathrm{Ca}$ channel blockers, beta blockers, diuretics, ASA) were found to be significant. The strongest correlation coefficient with the CCA IMT was found for age $(\mathrm{r}=0.710 ; p<0.001)$. All significant variables correlated positively with CCA IMT values (mean values of both CCAs), which means that an increase in these values was associated with an increase in CCA IMTs. Since this analysis showed an association at the univariate level, a multivariate regression model was developed further on: the CCA IMT value was used as the dependent variable, and all those that were statistically significant at the univariate level were used as predictor variables in the regression model. Since LDL was used to calculate the LDL/HDL index, only the LDL value was used to avoid redundancy in the multivariate model. The multivariate regression model explained $70.5 \%$ of the variance of the dependent variable (IMT of ACC) and was statistically significant $(p<0.001)$. 
The model thus distinguishes significant influences of three predictor variables that are positively associated with elevated CCA IMT values: $\mathrm{LDL}($ beta $=1.37 ; p=0.018)$, age (beta $=$ $0.444 ; p=0.001$ ), and TSH (beta $=0.336$; $p<0.001)$, with all other variables held constant.

\section{Table 4}

Univariate and multivariate regression model of prediction of increased CCA IMT

\begin{tabular}{|c|c|c|c|c|}
\hline \multirow{2}{*}{ IMT ACC prediction } & \multicolumn{2}{|c|}{ Univariate analysis } & \multicolumn{2}{|c|}{ Multivariate linear regresssion ${ }^{\dagger \dagger}$} \\
\hline & $\begin{array}{l}\text { Correlation } \\
\text { coefficient }\end{array}$ & $p$ & $\begin{array}{l}\text { Standardized beta } \\
\text { coefficient }\end{array}$ & $p$ \\
\hline Age (years) & 0.710 & $<0.001$ & 0.444 & 0.001 \\
\hline Cholesterol (mmol/L) & 0.435 & $<0.001$ & -0.704 & 0.069 \\
\hline Tryglicerides (mmol/L) & 0.268 & 0.007 & -0.002 & 0.983 \\
\hline $\mathrm{HDL}(\mathrm{mmol} / \mathrm{L})$ & 0.029 & 0.778 & & \\
\hline $\mathrm{LDL}(\mathrm{mmol} / \mathrm{L})$ & 0.436 & $<0.001$ & 1.370 & 0.018 \\
\hline sdLDL (mmol/L) & 0.345 & $<0.001$ & -0.187 & 0.203 \\
\hline LDL/HDL indeks & 0.318 & 0.001 & & \\
\hline Cholesterol/HDL indeks & 0.336 & 0.001 & 1.158 & 0.058 \\
\hline TSH (mlU/L) & 0.460 & $<0.001$ & 0.336 & $<0.001$ \\
\hline $\mathrm{fT} 4(\mathrm{pmol} / \mathrm{L})$ & -0.037 & 0.713 & & \\
\hline CRP (mg/L) & 0.327 & 0.001 & 0.122 & 0.079 \\
\hline BMI $(\mathrm{kg} / \mathrm{m} 2)$ & 0.371 & $<0.001$ & 0.082 & 0.293 \\
\hline Alcohol & 0.255 & 0.010 & 0.000 & 0.996 \\
\hline Smoking & -0.055 & 0.584 & & \\
\hline Positive family history & 0.087 & 0.388 & & \\
\hline Arterial hypertension & 0.393 & $<0.001$ & -0.231 & 0.063 \\
\hline Menopause & 0.623 & $<0.001$ & 0.029 & 0.800 \\
\hline ACE inhibitors & 0.296 & 0.003 & 0.138 & 0.155 \\
\hline Ca channel blockers & 0.227 & 0.023 & 0.104 & 0.215 \\
\hline Beta-blockers & 0.228 & 0.023 & 0.135 & 0.135 \\
\hline Angiotensine II antagonists & 0.159 & 0.114 & & \\
\hline Diuretics & 0.344 & $<0.001$ & 0.105 & 0.192 \\
\hline ASA & 0.287 & 0.004 & 0.071 & 0.364 \\
\hline
\end{tabular}

${ }^{\Uparrow}$ In this multivariate linear regression model, included were only those variables that were found significant in a univariate analysis with the level $p<0.05 ; \mathrm{r}^{2}=70.5 \%, p<0.001$.

ACE inhibitors - inhibitors of angiotensin converting enzyme; ASA - acetylsalicylic acid; BMI - body mass index; CRP - C-reactive protein; fT4 - free thyroxine; HDL - high-density lipoprotein; LDL - low-density lipoprotein; sdLDL - small dense low-density lipoprotein; TSH - thyrotropin. 


\section{DISCUSSION}

This study analyzed the effects of SHypo and dyslipidemia in women on changes in the walls of carotid artery, with the assumption that SHypo increased the risk of cardiovascular and cerebrovascular disease due to the effect of thyroid dysfunction on cardiovascular risk factors such as dyslipidemia, increased tendency for LDL oxidation and abnormal endothelial reactivity. The main results of this study showed that women with SHypo develop early signs of subclinical carotid atherosclerosis in the form of carotid wall thickening (IMT), with a more frequent occurrence of plaque than in the control (euthyroid) group.

\section{Clinical traits}

Given that arterial hypertension is known to have an impact on the rise of IMT, uniformity among the groups in this study is gaining in importance. In this study, 34\% of all subjects had arterial hypertension, with no significant difference between the study groups. So far, the results from different studies were non coherent. Meta-analysis from eight observational studies, reported by Gao et al., concluded that SHypo was associated with elevated systolic but not diastolic pressure [13]. On the other hand, the results of a study conducted by Luboshitzky and Herer showed that in the SHypo group there were higher values of both systolic $(p$ $<0.01)$ and diastolic $(p<0.001)$ pressure compared to the control group [14]. Lastly, in the study by Velkoska Nakova et al., mean systolic and diastolic pressures were higher in the SHypo group, with no statistically significant difference compared to the control (euthyroid) group [15].

In this study, consuming drugs that could affect the lipid and hormonal status of the thyroid gland was the exclusion criterion. Subject's personal drug report revealed that they mostly used analgesics (25\%) and various supplements such as vitamins and minerals (17\%), with no differences between the study groups.

The results of this study showed that the subjects with SHypo had significantly higher values of IMT (IMT $\geq 75$ th centile) in both carotid arteries compared to the control euthyroid subjects (Figure 2), with a significantly more frequent appearance of plaques (25\% vs. 9\%). Velkoska Nakova et al. reported similar results in a study in which average ACC (arteria carotis communis) IMT values in the SHypo group were significantly higher than in the control group $(0.61 \pm 0.1 \mathrm{~mm}$ vs. $0.56 \pm 0.1 \mathrm{~mm} ; p=0.034$ ), with a higher incidence of plaque occurrence in the SHypo group (10.1\% vs. 3.3\%) [15]. The results of the study conducted in Brazil also showed higher values of IMT in a group of subjects with SHypo [16]. In a metaanalysis in which Gao et al. analyzed eight observational studies, with 3602 patients, an increase in carotid IMT by $0.056 \mathrm{~mm}(95 \% \mathrm{CI}$ $0.020,0.092, p=0.002$ ) was observed in the SHypo group compared to the euthyroid group [13]. Aziz et al. published a meta-analysis investigating the association between IMT and SHypo, and the results of levothyroxine substitution treatment. Carotid IMT was found to be significantly higher in the SHypo group $(\mathrm{N}=$ 280) compared with the control euthyroid group (N $=263$ ) at baseline, and levothyroxine therapy in the SHypo subjects significantly reduced the thickness of carotid IMT and improved the subject lipid profile while modifying cardiovascular risk factors [17]. Moreover, the two studies conducted in China an inverse association between TSH and carotid IMT values, in which subjects with SHypo and lower TSH had higher carotid IMT values $[18,19]$.

There were only a few studies analysing association of SHypo and IMT specifically in female subjects. In the study conducted by Saif et al., which included 40 female patients with overt hypothyroidism, 30 female patients with SHypo and 40 female partients with normal thyroid functions, the results have shown that carotid IMT is significantly higher $(p<0.001)$ in patients with overt and SHypo than in subject of the control group [20]. On the other hand, Dias Cabral et al. did not find any significant change in mean carotid IMT after 12 months of L-thyroxine tratment, in study which included 32 female with mild SHypo [21].

\section{Predictors of subclinical carotid changes}

The results obtained by univariate regression analysis in this study showed that age, cholesterol, triglycerides, LDL, sdLDL, LDL/HDL index, TSH, CRP, BMI, alcohol consumption, arterial hypertension, and menopause correlated positively with mean IMT values in both CCAs (common carotid arteries).

Multivariate regression analysis showed that LDL, age, and TSH were positively associated with elevated CCA IMT values and thus predicted thickening of the carotid artery IMT (Table 4). In the study by Velkoska Nakova et al., TSH, triglycerides, and diastolic arterial pressure were 
found to be independent predictors of average IMT, while fT4 proved to be an independent predictor of maximum IMT [15]. Takamura et al. found, by multivariate linear regression analysis adjusted for age and gender, in a study involving 1,772 subjects, that fT4 significantly correlated with carotid IMT thickness (beta $=-0.13, p=0.043$ ), and TSH with HDL (beta $=-0.001, p<0.001$ ), HbA1c (beta $=0.04, p=0.021$ ), and carotid IMT (beta $=0.29, p=0.001)$. They showed that the thickness of carotid wall (IMT) was independently associated with thyroid function of the reference range, and that there was an increase in cardiovascular risk in individuals with low normal thyroid function [22].

Based on the results of this and other studies, it can be concluded that increased age, LDL cholesterol, and TSH values are important predictors of subclinical atherosclerotic changes development in carotid artery.

\section{Limitations of the study}

Lastly, it should be noted that the limitations of this study are a small sample size, and a retrospective design. A longitudinal study including higher number of subjects of both genders may help clarify the underlying mechanisms of SHypo and IMT association.

Another limitation of this study is that we did not measure quantitative variables such as the vital signs, blood work (glycemia, creatinine, estimated GFR, sodium, potassium, transaminases, complete blood count).

\section{CONCLUSION}

This study confirmed the hypothesis that female subjects with SHypo develop early subclinical changes on the walls of common carotid artery detected as elevated IMT in comparison to the female control euthyroid group.

Based on these results, it can be concluded that screening and monitoring of patients showing early subclinical signs of thyroid dysfunction shoud take part in prevention of carotid atherosclerosis advancement and its complications.

Introducere. Hormonii tiroidieni pot afecta sistemul cardiovascular, dar mecanismul în dezvoltarea aterosclerozei nu este bine definit. Relația dintre hipotiroidismul subclinic, dislipidemie și ateromatoza carotidiană a fost investigată însă rezultatele sunt încă controversate. Scopul studiului a fost de a evalua asocierea dintre hipotiroidismul subclinic (SHypo) și indicele carotidian intimă-medie (IMT) la femei. Totodată au fost căutate asocierile dintre SHypo, ateroscleroză carotidiană și dislipidemie.

Metode. Au fost incluse 100 de paciente cu vârste între 30 și 70 de ani, impărțite în două grupuri SHypo și eutiroidiene. A fost evaluat IMT alături de profilul lipidic (small dense LDL) și cel al hormonilor tiroidieni.

Rezultate. Pacientele cu Shypo aveau IMT mai mare în toate cele trei segmente comparativ cu pacientele eutiroidiene. Placa de aterom a fost mai frecventă la pacientele SHypo comparativ cu pacientele eutiroidiene (25\% vs $9 \%$ $p=0.05$ ). Au fost decelate asocieri pozitive intre nivelurile TSH și IMT. IMT a fost prezis de vârstă, LDL colesterol și nivelurile TSH.

Concluzii. Acest studiu subliniază importanța screeningului precoce al disfuncției tiroidiene și asocierea riscului cardiovascular.

Correspondence to: Maida Seferovic Saric, M.D, Zabok General Hospital and Hospital of Croatian Veterans, Department of Neurology, Bracak 8, 49210 Zabok, Croatia

E-mail: maiseferovic@ gmail.com, Phone: +385 49204 390,+385 98540 285, Fax: +385 49204373

Conflict of interest disclosure: The authors declare that there are no conflicts of interest. 


\section{REFERENCES}

1. WILSON GR., CURRY RW. Subclinical Thyroid Disease. Am Fam Physician. 2005;72(8):1517-1524.

2. MALEKI N., KAZEROUNI F., HEDAYATI M., RAHIMIPOUR A., PARHAM M. Subclinical Hypothyroidism and the Alterations of Lipid Profile as a Cardiovascular Risk Factor. J Paramed Sci. 2015;6(4):2008-4978.

3. RIZOS CV., ELISAF MS., LIBEROPOULUS EN. Effects of Thyroid Dysfunction on Lipid Profile. Open Cardiovasc Med J. 2011;5:76-84.

4. TOUBOUL PJ., ELBAZ A., KOLLER C., LUCAS C., ADRAI V., CHEDRU F., et.al. Common carotid artery intima-media thickness and brain infarction. Circulation. 2000;102:313-318.

5. WEBER F. Risk factors for subclinical carotid atherosclerosis in healthy men. Neurology. 2002;59:524-528.

6. DEMARIN V., LOVRENČIĆ-HUZJAN A. Neurosonologija. Zagreb: Školska knjiga; 2009. p. 88-92.

7. HOWARD G., SHARRETT AR., HEISS G., EVANS GW., CHAMBLESS LE., RILEY WA., ET AL. Carotid intimal-medial thickness distribution in general populations as evaluated by B-mode ultrasound. ARIC investigators. Stroke. 1993;24:1297-1304.

8. SOLTER M. Bolesti štitnjače - klinička tireoidologija. Zagreb: Medicinska naklada; 2007.

9. KARAGIANNIS AKA. and NAKOUTI T. The Role of Carotid Intima Media Thickness in Subclinical Hypothyroidism. A Systematic Review. Austin J Obes \& Metab Synd. 2020;4(2): 1020.

10. GONG N., GAO C., CHEN X., FANG Y., TIAN L. Endothelial Function in Patients with Subclinical Hypothyroidism: A MetaAnalysis. Horm Metab Res. 2019;51(11):691-702.

11. SEFEROVIC SARIC M., JURASIC MJ., SOVIC S., KRANJCEC B., GLIVETIC T., DEMARIN V. Dyslipidemia in subclinical hypothyroidism requires assessment of small dense low density lipoprotein cholesterol (sdLDL-C). Rom J Intern Med. 2017;55(3):159-166.

12. TOUBOUL PJ., HENNERICI MG., MEAIRS S., ADAMS H., AMARENCO P., BORNSTEIN N. Mannheim Carotid IntimaMedia Thickness and Plaque Consensus (2004-2006-2011). An Update on Behalf of the Advisory Board of the 3rd, 4th and 5th Watching the Risk Symposia, at the 13th, 15th and 20th European Stroke Conferences, Mannheim, Germany, 2004, Brussels, Belgium, 2006, and Hamburg, Germany, 2011. Cerebrovasc Dis. 2012;34(4):290-296.

13. GAO N., ZHANG W., ZHANG YZ., YANG Q., CHEN SH. Carotid intima-media thickness in patients with subclinical hypothyroidism: a meta-analysis. Atherosclerosis. 2013;227(1):18-25.

14. LUBOSHITZKY R., HERER P. Cardiovascular risk factors in middle-aged women with subclinical hypothyroidism. Neuroendocrinol Lett. 2004;85:1049-1053.

15. VELKOSKA NAKOVA V., BOSEVSKI M., DIMITROVSKI C., KRSTEVSKA B. Subclinical hypothyroidism and risk to carotid atherosclerosis. Arq Bras Endocrinol Metabol. 2011;55(7):475-480.

16. PEIXOTO DE MIRANDA EJF., BITTENCOURT MS., PEREIRA AC., GOULART AC., SANTOS IS., LOTUFO PA. Subclinical hypothyroidism is associated with higher carotid intima-media thickness in cross-sectional analysis of the Brazilian Longitudinal Study of Adult Health (ELSA-Brasil). Nutr Metab Cardiovasc Dis. 2016;26:915-921.

17. AZIZ M., KANDIMALLA Y., MACHAVARAPU A., SAXENA A., DAS S., YOUNUS A., et al. Effect of Thyroxin Treatment on Carotid Intima-Media Thickness (CIMT) Reduction in Patients with Subclinical Hypothyroidism (SCH): a Meta-Analysis of Clinical Trials. J Atheroscler Thromb. 2017;24(7):643-659.

18. FENG X., ZHAO L., JIANG J., MA W., SHANG X., ZHOU Q., et al. Discriminatory value of carotid artery elasticity changes for the evaluation of thyroid dysfunction in patients with hashimoto's thyroiditis. J Clin Ultrasound. 2016;44:298-304.

19. ZHOU Y., ZHAO L., WANG T., HONG J., ZHANG J., XU B., et al. Free Triiodothyronine concentrations are inversely associated with elevated carotid intima-media thickness in middle-aged and elderly Chinese population. J Atheroscler Thromb. 2016;23(2):216-224.

20. SAIF A., MOUSA S., ASSEM M., THARWAT N. and ABDELHAMID A. Endothelial dysfunction and the risk of atherosclerosis in overt and subclinical hypothyroidism. Endocr Connect. 2018;7(10):1075-1080.

21. DIAS CABRAL M., TEIXEIRA P., SOARES D., LEITE S., SALLES E., and WAISMANL M. Effects of thyroxine replacement on endothelial function and carotid artery intima-media thickness in female patients with mild subclinical hypothyroidism. Clinics (Sao Paulo). 2011; 66(8):1321-1327.

22. TAKAMURA N., AKILZHANOVA A., HAYASHIDA N., KADOTA K., YAMASAKI H., USA T., ET AL. Thyroid function is associated with carotid intima-media thickness in euthyroid subjects. Atherosclerosis. 2009;2004(2):77-81.

Received $9^{\text {th }}$ February 2021 